\title{
THE IMPACT OF HIGHWAY INVESTMENT ON NEW MANUFACTURING EMPLOYMENT IN SOUTH CAROLINA: A SMALL REGION SPATIAL ANALYSIS
}

\author{
Loretta Singletary, Mark Henry, Kerry Brooks and James London*
}

\begin{abstract}
A geographical information system (GIS) is used with econometric methods to develop a small region spatial model to analyze the linkage between highway investment and new manufacturing employment in South Carolina. OLS estimates of the spatial model indicate that increases in four-lane highways, as well as interstate access, and two-lane highway density stimulate new manufacturing firm employment. Regions with higher than average employment density (a proxy for agglomeration economies) consistently influence employment gains as well, however. An implication for state and local policymakers is that the location, timing, and type of highway investment matter concerning whether highway investment serves as an economic development aid. Comparison of nonspatial and spatial model results indicates that development of small region models incorporating spatial statistical concerns should be pursued further.
\end{abstract}

\section{INTRODUCTION}

A firm's location decision is theoretically the result of optimizing behavior. In considering alternate locations, firms examine differences in product demand and production costs. As wage labor and land prices differ by location, firms presumably have reliable information about these differences and can select a location where profits can be maximized (Gerking and Morgan 1991). Under the public capital hypothesis, increased regional investment in physical infrastructure, such as highways, helps to minimize transportation costs to firms, thereby increasing the rate of return to private investment. Public investment, in the form of a new or expanded highway, may initiate a cycle of private capital investment that will stimulate output and employment growth in that region.

This neoclassical development scenario is characterized by mobile inputs that flow freely to regions offering the highest rate of return to investment. While workers are attracted to areas with higher wages, improved education, and local amenities, private capital location is influenced by factor price differences and transportation costs. Conversely, productivity growth may spawn regional growth

\footnotetext{
*Assistant Professor, Department of Agricultural Economics and Rural Sociology, The Pennsylvania State University; Professor, Department of Agricultural and Applied Economics, Clemson University; Assistant Professor, Department of Planning Studies, Clemson University; and Associate Professor, Department of Planning Studies, Clemson University, respectively.
} 
so that firms reap added savings in transportation time by purchasing inputs locally (Eberts 1990; 1991).

Empirical research has produced an archive of inconclusive evidence regarding the nature of any linkage that may exist between highway investment and local economic development (see Humphrey and Sell 1970; Kuehn and West 1971; Miller 1979; Briggs 1980; Wilson et al. 1985; Burress and Clifford 1989; Tatom 1991). Yet, economic development "strategies" to generate growth by attracting industry via highway development and improvement have become increasingly focal points of state and local policy. Rephann's (1993) exhaustive review of highway empirical studies suggests that regional forces exist that "trigger growth." Researchers have identified and tested such triggering forces as ". . geographical region, urbanization and proximity to metropolitan areas, prior growth and development conditions, and other types of public infrastructure ..." (Rephann 1993). There appears to be some concurrence that highways are more stimulating for urbanized areas located near metropolitan areas in less developed regions, while underdeveloped regions do not respond well to investment. A location decision analysis conducted by Calzonetti and Walker (1991) indicates that market accessibility tends to be the most important factor influencing industrial location. They suggest that there is little local development officials can do to affect this variable besides improving highways and interstate access.

While many studies concede that highway investment impacts can be illustrated in the short term in the form of construction jobs, there is greater variability in assessing long-term effects. These impacts are anticipated to be expressed as number of jobs created through increased industrial and business activity stimulated by increased mobility and reduced costs of input factors, improved market accessibility, and lower transportation costs. Estimation of these longer-term effects has been complicated in part due to model specification and design. Most research expresses some chronic concern over the potential for simultaneity bias-or more commonly expressed as- which comes first, the highways or the jobs? An unpriced public service, such as highways, is typically associated with increased productivity and reduced costs to businesses, thereby increasing business growth. Illustrating this association, as Bartik (1991) notes however, is problematic in that many potential (business) location determinants, such as taxes, land prices, and wages, many be endogenously determined by business growth. Munnel (1990) uses an aggregate production function framework to test whether there is a positive relationship between output and public capital at the state and multistate level. She finds that those states investing more in infrastructure tend to have greater output, more private investment, and more employment growth. Although the direction of causality indicates that public investment comes before an economic pickup in activity, Munnel expresses some 
uncertainty concerning the specific nature of the linkage. Eberts (1990) asserts that the relationship between regional economic growth and local public infrastructure investment is simultaneous. That is, public capital, such as highways, can be viewed as production inputs to private industry but are provided by the government and financed through taxes. Since firms do not control the supply of public capital, it remains an exogenous input to their production. Yet, allocation of this public capital is endogenous to a regional economy since it is the local political process that largely determines the level of public capital outlay.

Further complicating model specification and design has been a lack of comprehensive estimates of highway investment. In circumventing a lack of data, many analyses have used proxies for highway investment in order to estimate its contribution to output. Aschauer (1990), for example, in estimating the influence of highway capacity on state per capita income growth, approximates public capital as "vehicular density" per time period and miles of highway. He links these proxies to state-level regional growth via a neoclassical production function, concluding that added road capacity over the period 1960-1985 leads to added growth in per capita income. And, increased rural road capacity affects growth rates more so than urban roads. Isserman et al. (1989) adapt quasi-experimental techniques using as a proxy for highway investment the location and timing of specific highway projects. They compare growth differences between regions receiving highway investment and similar regions not receiving highway investments. Their results indicate that although there are benefits associated with linking a city and its county to the interstate system, no significant benefits continue after the construction phase.

Several studies (see Richardson 1973; Nijkamp 1986; Baerwald 1982) maintain that a crucial factor in estimating the economic impact of highway investment is timing of investment. In early stages of a region's economic development, a new highway may encourage economic growth whereas in later stages, it simply improves personal mobility. Several analyses similarly suggest that regional economic development is attributed to a number of forces besides physical infrastructure factors, including evolution of political, social, and institutional resources (see Storper 1986; Arthur 1989, 1990; Krugman 1991). Hence, infrastructure policy designed for the sole purpose of stimulating growth in regional employment cannot disregard timing of infrastructure investment.

Another obstacle to reliable estimation has been the potential for spatial statistical concerns associated with estimating the influences of physically fixed investment such as highways. Researchers have for the most part depended on municipal or political boundaries to define regional geography for highway investment. The examination of interrelationships among small contiguous regions within one state is rare largely because of the threat to statistical confidence of the 
potential "spillover effects" across small regions, such as Census County Divisions (CCDs) or Minor Civil Divisions (MCDs). In response, much of the research on regional highway impacts has focused on effects on large geographic areas such as states and metropolitan areas across the United States. Since highway investment decisions are frequently developed within state boundaries, rather than across states; however, a within state analysis of these activities is valuable. Further, state-level infrastructure policy is often designed to target specific small regional development sites within state boundaries and is not designed to garner regional effects that are multistate or multimetropolitan in geographic scope.

Fox and Murray (1990) provide an exception in their analysis of the association between added infrastructure and firm start-ups. They generate a linear regression model from an indirect profit function representing the firm manager's effort to select the location that optimizes wage or profit and provides the best combination of local amenities in order to maximize total individual welfare. ${ }^{1}$ They find that short-term policies, such as property, sales, and local business tax rate increases, discourage firm entries, while long-term policies, such as infrastructure and educational investment, produce more robust and positive results.

\section{CREATING A SMALL REGION MODEL}

Economic development policy initiatives designed to stimulate growth in South Carolina have relied historically on improvements in public capital, particularly four-lane highway construction projects, to recruit new manufacturing firms. State policy has emphasized such recruitment tactics to the extent of discerning between durable and nondurable product manufacturing firms.

The objective of this study is to create an intrastate small region model to estimate the influence on new manufacturing employment of four-lane highway investment. The model considers location, timing, and type of highway investment in its design as well as spatial statistical obstacles to small region analysis.

The linear regression model generated here adapts Fox and Murray's conceptual model represented by the firm manager's welfare function. The profitseeking firm manager locates a new firm at a point in space in order to maximize his welfare by optimizing opportunity wage through increased firm profits and optimal consumption of amenities in each potential firm site. ${ }^{2}$ The connection between infrastructure and firm location decisions, in this case, views four-lane highways as a direct input to the firm's production process. Four-lane highways provide profit opportunities by offering firms reduced costs for transporting input factors to production and for shipping output to markets. As amenities, new highways serve to move workers to and from work more efficiently. 
To analyze the intrastate effects of four-lane highways, the political subdivisions by which socioeconomic data are reported for South Carolina, Census County Divisions (CCDs) are disaggregated to smaller geographical units via a Geographic Information System (GIS). The GIS procedure is used to increase the number of cross-sectional observations and to decrease the size of each geographical unit arbitrarily by overlaying the state's zip code regions with the $296 \mathrm{CCDs}$ producing 477 smaller geographical units. These smaller units provide for selection of intrastate "impact regions" to be defined based on: (1) location or proximity to a four-lane project and (2) timing of a highway project. Historical highway data, available for the 1960-1989 period, are adapted for GIS usage so that "impact" regions can be defined by: (1) 5 kilometer proximity to a new fourlane highway and (2) when a project was implemented over five possible time periods between 1960 and $1989 .{ }^{3}$ To isolate the influence of four-lane highways in stimulating new employment, the model controls for the influence of other potential influential infrastructure variables. In this case, these include a region's ramp access to an Interstate highway; access to interstate 85 , which connects South Carolina with the two closest and largest metropolitan areas in the Southeastern region-Charlotte, North Carolina, and Atlanta, Georgia; two-lane highway capacity; and level of water or sewer capacity by 1980 .

Previous research suggests that regional agglomeration economies may generate potential profit by signalling to private investors that preconditions to growth in a region exist and that amenities are more readily available. Agglomeration economies presumably include a wider selection and availability of local labor and capital inputs, a larger more diversified market area, and reduced transportation costs for localized inputs and outputs. To isolate the influence of four-lane highways through controlling for agglomeration effects, the model approximates agglomeration economies with variables measuring initial manufacturing employment density in a region by 1980 and a region's proximity to the state's five urban core areas. ${ }^{4}$

\section{SPATIAL CONCERNS AND THE RESULTING SMALL REGION MODEL}

Such multidimensional spatial controls over cross-sectional observations are expected to counteract potential econometric problems frequently encountered, but not always confronted, in small region analysis-specifically, spatial heterogeneity and spatial autocorrelation. Spatial heterogeneity refers to a "lack of stability over space of the behavioral or other relationships under study" (Anselin $1988 ; 9)$. The instability suggests that parameters vary over space with respect to 
location and are heterogeneous, rather than homogeneous, throughout a set of data. It is more likely to occur in "econometric models estimated on a cross-sectional data set of dissimilar spatial units" (Anselin 1988, 9). Remaining error may emanate from spatial autocorrelation or spillover effects due to the close spatial proximity or adjacency of the cross-sectional observations.

To adjust for these concerns, Cliff and Ord (1981) and Anselin (1988) suggest construction of a spatial contiguity matrix. The contiguity matrix, in this case, contains information for the total number of spatial units or observations that are contiguous or border other units for each of the 477 cross-sectional observations. This information should help to determine the extent to which creating more spatially refined impact regions reduces or aggravates econometric concerns, such as spatial heterogeneity and autocorrelation, and may be used to adjust the econometric model accordingly.

GIS software, ARCINFO, provides a procedure that allows assembly of a list of the 477 spatial units with their contiguous or bordering units. This information is used with SAS/IML to construct a 477 by 477 binary matrix, W, whose elements equal 1 if units have a contiguous boundary and zero otherwise.

Bernirschka (1991) outlines the steps necessary to convert the binary matrix, $W$, into a symmetric contiguity matrix or spatial weight matrix, $\bar{W}$, for use in controlling for spatial problems. Basically, a similarity transformation is applied to matrix $W$ so that it is symmetric, $W^{*}$. Then the matrix $W *$ is standardized and normalized through pre- and post-multiplication by a diagonal matrix, $D$, whose diagonal elements are the inverted row sums of $W^{*}$ (Bernirschka 1990, 174). The transformation is

$$
\bar{W}=D^{1 / 2} W^{*} D^{1 / 2}
$$

While $W$ is asymmetric, $W^{*}$ is symmetric. Thus, $\bar{W}_{i s}$ a symmetric standardized and normalized spatial weight matrix representing the degree of contiguity, and thus spatial interaction, of small regions as indicated in matrix $W$.

The spatial autoregressive equation suggested by Cliff and Ord $(1981,231)$ is

$$
Y=\rho \bar{W} Y+X \beta i+\varepsilon i
$$


where $\bar{W}$ is the spatial weight matrix and $\rho$ and $\beta$ ( $k$ X 1 vector) are parameters. The errors are assumed to be normally distributed with zero means and equal variances.

The transformed variable is included as a regressor in the OLS equation to control for structural instability over space and serves as an indicator for the degree of spatial autocorrelation present. The equation estimated including the transformed dependent variable is

$$
\begin{aligned}
E M P 80= & \alpha+\rho \bar{W}(E M P 80)+\beta 1 \text { EMP79 }+\beta 22 L N H W Y+\beta 3 R A M P+ \\
& \beta 4185+\beta 5 W S+\beta 6 H W Y 8+\beta 7 H W Y 67+\beta 8 H W Y 68+ \\
& \beta 9 H W Y 78+\beta 10 H W Y 678+\beta 11 U R B A N+\beta 12 T H R E S H+\varepsilon i .
\end{aligned}
$$

Variable definitions are

EMP79

2LNHWY

RAMP

185

WS

HWY8

HWY67

HWY68

HWY78

HWY678

URBAN

THRESH number of employees in firms established by 1980 .

number of kilometers of commercially available two-lane road in a region divided by the region area.

1 if the region contained an interstate ramp, else RAMP $=0$.

1 if the region is traversed by Interstate Highway 85, which connects Charlotte, North Carolina, and Atlanta, Georgia, else $185=0$.

number of kilometers of commercially suitable water and sewer lines weighted by the dimension (in inches) of the lines that were completed by 1980 .

the number of employees by 1980 in regions that first had a four-lane highway improvement in the 1980 s.

the number of employees by 1980 in regions that first had a four-lane highway improvement in the 1960s and 1970s.

the number of employees by 1980 in regions that first had a four-lane highway in the 1960s and 1980s.

the number of employees by 1980 in regions that first had a four-lane highway in the 1970s and 1980s.

the number of employees by 1980 in regions that first had a four-lane highway in the 1960s, 1970s, and 1980s.

1 if the region is an urban core region, else URBAN $=0$.

1 if the region is within a buffer zone greater than $5 \mathrm{~km}$ but less than $10 \mathrm{~km}$ from an urban core region. 
EMP80 the number of employees in firms established during the
1980s.

E8TR a spatially lagged construction of EMP80, W(EMP80).

The dependent variable EMP80 is the total employment in firms starting business in the 1980s from the 1989 Dun and Bradstreet files for South Carolina and the 1989 South Carolina Industrial Directory files. Both data files were available in geocoded format-longitude and latitude coordinates were assigned to each observation-- to provide compatibility with GIS procedures. ${ }^{5}$ Agglomeration forces are approximated by initial employment levels. It is expected that if agglomeration forces are persuasive in shaping future employment, then higher levels of EMP79, regional employment by 1980, will positively influence employment addition over the 1980s.

The variable 2LNHWY measures the density of two-lane highway stock in each region. GIS is used to construct qualitative indicators of interstate access in each region. First, those regions are selected that are traversed by the Interstate 85 (I-85) corridor that connects South Carolina communities with the largest cities in adjacent states (Charlotte, North Carolina and Atlanta, Georgia). Also, those regions are selected that contain at least one interstate access ramp, RAMP. Only 98 regions have interstate ramp access, and only 22 lie on the I-85 corridor. It is expected that 2LNHWY, 185, and RAMP will each have positive influences on region employment additions in the 1980s.

In the empirical form of the model, four-lane highway variables are used to represent the decade(s) in which a region received (e.g., located within 5 kilometers of) a new four-lane highway project. For example, if $\mathrm{HWY} 8=1$, then the region had a four-lane project in the 1980s only; if HWY $8=0$, then the region did not have a four-lane project only in the 1980s. To test for direction of causality, the indicator variables are transformed into interaction variables by multiplying each of these highway treatment variables times the initial employment activity in a region (EMP79).

A final control variable for infrastructure effects is the stock of water and sewer investment prior to 1980 . The variable, WS, is found by summing over the length of each line built by decade and by size. It is expected that added water and sewer capacity by 1980 will positively affect region employment growth over the 1980s.

With respect to agglomeration forces and the geographic location of each impact region, GIS aids in identifying urban, threshold (urban-fringe), and rural regions in the state. Similar to von Thunen's concentric ring theory of economic spatial patterns, these allocations are based on the construction of $5 \mathrm{~km}$ and $10 \mathrm{~km}$ circular buffer zones around the five urban complexes in South Carolina. The 89 
regions that are primarily within the $5 \mathrm{~km}$ zone surrounding the metropolitan central cities of Greenville, Spartanburg, Columbia, Rock Hill, Florence, Charleston, and Aiken are considered urban. There are 115 regions between $5.01 \mathrm{~km}$ and $10 \mathrm{~km}$ from these metropolitan areas. These are the urban-fringe areas or threshold areas that might be described as sub-urban areas additionally. The remaining regions are classified as rural. As distance away from the urban core regions increases, agglomeration influence on employment addition is expected to diminish.

Equation (3) is estimated for the durable and nondurable manufacturing industry divisions using the regions as cross-sectional observations. In sum, the model goals are (1) to control for the initial agglomeration effects in each region that influence its potential for attracting new firms, and (2) to evaluate the effects on employment gains from new firms (1980 through 1989) if a given region has more infrastructure in place by 1980 than the average region in South Carolina.

The nonspatial model estimates of added 1980s employment (EMP80) using standard OLS are compared with the spatial OLS estimates for the two manufacturing industry divisions. If spatial heterogeneity or instability of the estimates of 1980s employment over space exists, there should be substantial parameter variation between the spatial model estimates and the nonspatial model estimates. If spatial autocorrelation or spillover effects exist, then the parameter estimate for the influence of the spatially lagged variable, E8TR, should differ significantly from zero.

\section{EMPIRICAL RESULTS}

Tables 1 and 2 list the OLS estimates for the nonspatial and spatial models, respectively, for the durable manufacturing sector, while Tables 3 and 4 list the nonspatial and spatial results for the nondurable manufacturing sector. Although the F-statistics for both models are significant for both industry divisions, the adjusted R-squares for the spatial model are larger than those for the nonspatial model. This suggests that the spatial model succeeds in explaining more of the total variation in 1980s employment change than the nonspatial model.

Comparisons of nonspatial OLS estimates with the spatial OLS estimates reveal some variation in estimates of the influence of infrastructure on attracting new manufacturing employment. For both industry divisions, the nonspatial parameter OLS estimates tend to be larger than the spatial model estimates and sign reversals exist for the variables THRESH (Tables 1 and 2) and 185 and RURAL (Tables 3 and 4). Spatial autocorrelation is present as well, as indicated by the lagged variable, E8TR, which significantly differs from zero. This suggests 


\section{TABLE 1}

Durable Manufacturing Employment Additions, 1980-89: OLS Estimates Non-spatial Model

Nonspatial Model:

Analysis of Variance-from Mean

\begin{tabular}{|c|c|c|c|c|}
\hline Source & DF & $\begin{array}{l}\text { Sum of } \\
\text { Squares }\end{array}$ & $\begin{array}{l}\text { Mean } \\
\text { Square } \\
\end{array}$ & F Value \\
\hline Model & 14 & $0.84225 E+07$ & $0.70187 E+06$ & 11.689 \\
\hline Error & 464 & $0.16471 E+08$ & 35499. & PROB $>F$ \\
\hline Total & 476 & $0.24894 \mathrm{E}+08$ & 52298. & 0.0001 \\
\hline Variable Name & \multicolumn{3}{|c|}{ Estimated Coefficient } & T-ratio \\
\hline EMP79 & \multicolumn{3}{|c|}{$0.63326 \mathrm{E}-01$} & $1.3052^{\mathrm{a}}$ \\
\hline 2LNHWY & \multicolumn{3}{|c|}{$0.62466 \mathrm{E}-03$} & $2.1591^{\mathrm{ab}}$ \\
\hline RAMP & \multicolumn{3}{|c|}{58.519} & $1.9249^{\mathrm{ab}}$ \\
\hline I85 & \multicolumn{3}{|c|}{119.44} & $1.3444^{\mathrm{a}}$ \\
\hline WS & \multicolumn{3}{|c|}{$0.83337 \mathrm{E}-03$} & $1.9531^{\mathrm{ab}}$ \\
\hline HWY8 & \multicolumn{3}{|c|}{0.15024} & 0.70254 \\
\hline HWY67 & \multicolumn{3}{|c|}{0.11132} & $1.9544^{\mathrm{ab}}$ \\
\hline HWY68 & \multicolumn{3}{|c|}{$-0.26862 E-01$} & -0.41385 \\
\hline HWY78 & \multicolumn{3}{|c|}{-0.19528} & $-2.1050^{b}$ \\
\hline HWY678 & \multicolumn{3}{|c|}{0.16040} & $1.7049^{\mathrm{ab}}$ \\
\hline URBAN & \multicolumn{3}{|c|}{87.563} & $2.7081^{\mathrm{ab}}$ \\
\hline THRESH & \multicolumn{3}{|c|}{35.749} & $1.5346^{\mathrm{a}}$ \\
\hline CONSTANT & \multicolumn{3}{|c|}{-20.748} & $-2.1154^{b}$ \\
\hline
\end{tabular}

R-Square $=0.3383$

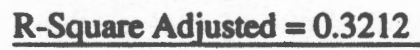

Standard Error of the Estimate $=188.41$

Mean of Dependent Variable $=83.717$

\footnotetext{
${ }^{\mathrm{a}}$ At 10 percent level of significance: rejection of one-tail test $\mathrm{Hol}_{1} \mathrm{~b}_{\mathrm{i}} \leq 0$, acceptance of $\mathrm{Ha}_{1}$ : $\mathrm{b}_{\mathrm{i}}>\mathbf{0}$.

${ }^{b}$ At 10 percent level of significance rejection of two-tail test $\mathrm{Ho}_{2}: b_{i}=0$, acceptance of $\mathrm{Ha}_{2}: \mathrm{b}_{\mathrm{i}} \equiv \mathbf{0}$.
} 
TABLE 2

Durable Manufacturing Employment Additions, 1980-89: OLS EstimatesSpatial Model

Spatial Model:

Analysis of Variance-from Mean

\begin{tabular}{|c|c|c|c|c|}
\hline Source & DF & $\begin{array}{l}\text { Sum of } \\
\text { Squares }\end{array}$ & $\begin{array}{l}\text { Mean } \\
\text { Square }\end{array}$ & F Value \\
\hline Model & 13 & 10294878.87 & 791913.76 & 25.115 \\
\hline Error & 463 & 14599047.92 & 31531.42099 & PROB > F \\
\hline Total & 476 & 24893926.79 & & 0.0001 \\
\hline Variable Name & \multicolumn{3}{|c|}{ Estimated Coefficient } & T-ratio \\
\hline$\overline{\text { E8TR }}$ & \multicolumn{3}{|c|}{0.73031083} & $7.706^{\mathrm{ab}}$ \\
\hline EMP79 & \multicolumn{3}{|c|}{0.05203422} & $3.125^{\mathrm{ab}}$ \\
\hline 2LNHWY & \multicolumn{3}{|c|}{0.000545497} & $2.482^{\mathrm{ab}}$ \\
\hline RAMP & \multicolumn{3}{|c|}{30.87822103} & $1.397^{a}$ \\
\hline 185 & \multicolumn{3}{|c|}{68.95981499} & $1.626^{\mathrm{a}}$ \\
\hline ws & \multicolumn{3}{|c|}{0.001009510} & $3.054^{\mathrm{ab}}$ \\
\hline HWY8 & \multicolumn{3}{|c|}{0.16971823} & $1.872^{\mathrm{ab}}$ \\
\hline HWY67 & \multicolumn{3}{|c|}{0.10441840} & $3.583^{\mathrm{ab}}$ \\
\hline HWY68 & \multicolumn{3}{|c|}{-0.09449603} & -1.260 \\
\hline HWY78 & \multicolumn{3}{|c|}{-0.21466323} & -0.495 \\
\hline HWY678 & \multicolumn{3}{|c|}{0.12690813} & $3.419^{\mathrm{ab}}$ \\
\hline URBAN & \multicolumn{3}{|c|}{0.18499073} & 0.007 \\
\hline THRESH & \multicolumn{3}{|c|}{-11.31136560} & -0.527 \\
\hline CONSTANT & \multicolumn{3}{|c|}{-43.71948200} & $-3.236^{b}$ \\
\hline
\end{tabular}

R-Square $=0.4135$

R-Square Adjusted $=0.3971$

Standard Error of the Estimate $=177.57$

Mean of Dependent Variable $=83.717$

\footnotetext{
${ }^{a}$ At 10 percent level of significance: rejection of one-tail test $\mathrm{Hol}_{\mathrm{l}} \mathrm{bi} \leq 0$, acceptance of $\mathrm{Ha}_{1}: \mathrm{b}_{\mathrm{i}}>0$.

${ }^{b}$ At 10 percent level of significance: rejection of two-tail test $\mathrm{Ho}_{2}: b_{i}=0$, acceptance of $\mathrm{Ha}_{2}: \mathrm{bi}_{\mathrm{i}} \equiv \mathbf{0}$.
} 
TABLE 3

Nondurable Manufacturing Employment Additions, 1980-89: OLS Estimates Nonspatial Model

Nonspatial Model:

Analysis of Variance-from Mean

\begin{tabular}{|c|c|c|c|c|}
\hline Source & DF & $\begin{array}{l}\text { Sum of } \\
\text { Squares }\end{array}$ & $\begin{array}{l}\text { Mean } \\
\text { Square }\end{array}$ & F VALUE \\
\hline Model & 12 & $0.15779 E+07$ & $0.13149 E+06$ & 5.550 \\
\hline Error & 464 & $0.10994 E+08$ & 23694. & $\mathrm{PROB}>\mathrm{F}$ \\
\hline Total & 476 & $0.12572 E+08$ & 26412. & 0.0001 \\
\hline Variable Name & \multicolumn{3}{|c|}{ Estimated Coefficient } & T-ratio \\
\hline EMP79 & \multicolumn{3}{|c|}{$0.88302 \mathrm{E}-01$} & $2.5966^{\mathrm{ab}}$ \\
\hline 2LNHWY & \multicolumn{3}{|c|}{$0.33157 \mathrm{E}-03$} & $1.4230^{\mathrm{a}}$ \\
\hline RAMP & \multicolumn{3}{|c|}{39.203} & $1.4828^{\mathrm{a}}$ \\
\hline 185 & \multicolumn{3}{|c|}{22.394} & 0.49455 \\
\hline WS & \multicolumn{3}{|c|}{$0.17287 E-03$} & 0.90937 \\
\hline HWY8 & \multicolumn{3}{|c|}{0.16009} & $1.7582^{\mathrm{ab}}$ \\
\hline HWY67 & \multicolumn{3}{|c|}{$-0.53463 E-01$} & -1.2684 \\
\hline HWY68 & \multicolumn{3}{|c|}{$0.99108 \mathrm{E}-01$} & 0.54127 \\
\hline HWY78 & \multicolumn{3}{|c|}{-0.29722} & -2.2652 \\
\hline HWY678 & \multicolumn{3}{|c|}{ 0.88907E-01 } & 1.0302 \\
\hline URBAN & \multicolumn{3}{|c|}{-23.543} & -1.4043 \\
\hline THRESH & \multicolumn{3}{|c|}{-33.452} & -1.6027 \\
\hline CONSTANT & \multicolumn{3}{|c|}{22.120} & $3.0003^{\mathrm{ab}}$ \\
\hline
\end{tabular}

R-Square $=0.1255$

R-Square Adjusted $=0.1029$

Standard Error of the Estimate $=153.93$

Mean of Dependent Variable $=53.302$

\footnotetext{
${ }^{\mathrm{a}}$ At 10 percent level of significance: rejection of one-tail test $\mathrm{Ho}_{1}: \mathrm{b}_{\mathrm{i}} \leq 0$, acceptance of $\mathrm{Ha}_{1}: b_{i}>0$.

${ }^{b}$ At 10 percent level of significance: rejection of two-tail test $\mathrm{Ho2}_{2}$ : $b_{i}=0$, acceptance of $\mathrm{Ha}_{2}: b_{i} \equiv 0$.
} 
TABLE 4

Nondurable Manufacturing Employment Additions, 1980-89: OLS Estimates Spatial Model.

Spatial Model:

Analysis of Variance-from Mean

\begin{tabular}{|c|c|c|c|c|}
\hline Source & DF & $\begin{array}{l}\text { Sum of } \\
\text { Squares }\end{array}$ & $\begin{array}{l}\text { Mean } \\
\text { Square }\end{array}$ & FVALUE \\
\hline Model & 13 & 3106512.64 & 238962.51 & $11 . .689$ \\
\hline Error & 463 & 9465391.89 & 20443.61099 & $\mathrm{PROB}>\mathrm{F}$ \\
\hline Total & 476 & 12571904.53 & & 0.0001 \\
\hline
\end{tabular}

Variable Name

Estimated Coefficient

T-ratio

E8TR

0.82697251

$8.647^{\mathrm{ab}}$

EMP79

0.07185563

$3.762^{\text {ab }}$

2LNHWY

0.000170839

0.963

RAMP

29.33870336

$1.670^{\mathrm{ab}}$

185

$-6.52449543$

$-0.191$

WS

0.000411320

$1.634^{\mathrm{a}}$

HWY8

0.16977547

$2.616^{\mathrm{ab}}$

HWY67

$-0.04054167$

$-1.749^{b}$

HWY68

0.005680217

0.067

HWY78

$-0.11351240$

$-0.185$

HWY678

0.04944355

0.606

URBAN

$-15.63032111$

$-0.793$

THRESH

$-29.85918994$

$-1.796^{\mathrm{b}}$

CONSTANT

$-15.26045481$

$-1.334$

R-Square $=0.2471$

R-Square Adiusted $=0.2260$

Standard Error of the Estimate $=142.9812$

Mean of Dependent Variable $=53.302$

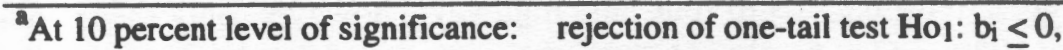
acceptance of $\mathrm{Ha}_{1}: \mathrm{b}_{i}>0$.

${ }^{b}$ At 10 percent level of significance: rejection of two-tail test $\mathrm{Ho}_{2}: b_{i}=0$, acceptance of $\mathrm{Ha}_{2}: \mathrm{bi}_{i} \equiv 0$.
} 
that ignoring such spatial concerns affects the parameter estimator. Looking at the spatial estimates for durable manufacturing listed in Table 2, regions with initial employment levels of 1,000 employees greater than the mean gained 52 more jobs in the 1980s. The spatial OLS estimates indicate no significant marginal effects on jobs created due to proximity to urban areas in South Carolina. The more rural regions, however, or those more isolated from urban core areas, lost jobs in durable manufacturing firms in the 1980s.

For each additional kilometer above average of two-lane highway density in a region, five new jobs were added, all else the same. Interstate access and proximity to I-85 significantly contributed to employment addition in the 1980s in this industry, adding 31 and 69 durable manufacturing jobs, respectively. Regions with 10,000 units of water/sewerage capacity above average prior to 1980 added 10 durable manufacturing jobs in the 1980s. Regions with initial employment levels 1,000 employees above the mean prior to 1980 that received four-lane highway projects during the 1980 s only, the 1960 s and 1970 s only, and in the 1960s, 1970s, and 1980s only, added 170, 104 and 127 more jobs, respectively, during the 1980s, all else the same.

Looking at Table 4, the spatial estimates for the nondurable manufacturing industry, agglomeration effects, as approximated by initial employment levels, encouraged new nondurable manufacturing jobs in the 1980s. Regions with initial employment levels of 1,000 employees greater than the mean gained 72 jobs in the $1980 \mathrm{~s}$ in this industry. For both industry types, the location of impact regions adjacent to urban core areas mattered little concerning whether a region realized new jobs, as these results were not statistically significant. Regions located at the urban fringe or threshold of urban cores, however, lost nondurable manufacturing jobs during this time period, while remote or isolated regions lost durable manufacturing jobs.

Nondurable manufacturing job gains were influenced by increased two-lane road density ( 2 jobs); interstate access ( 29 jobs), and; water and sewerage capacity (4 jobs). With regards to four-lane highways, however, only those constructed in the 1980s added nondurable manufacturing jobs in the 1980s. A statistical issue that may remain a threat to the validity of the spatial model is simultaneity bias. In this case, the correlation between the 1980s interaction highway variable and the dependent variable, ET80s, may produce inconsistent parameter estimates, biased variance, and thus invalid t-statistics for hypothesis testing. Conventional means (2SLS) could not be used to test for and correct simultaneous causality of 1980s highway investment and 1980s employment addition, however. The variables suspected as being endogenous in this case are the products of initial employment conditions and highway treatment dummy variables, or in other words, linear combinations of the independent variable EMP79, 
the sum of all employment in firms established through 1979. A Hausman (1978) Specification Test to test for exogeneity of these independent variables failed for the same reason. An ad hoc procedure involved respecifying the model by omitting the 1980s highway variables suspected as the source of bias and using as interaction variables four-lane projects implemented in the 1960s and 1970s, 1960s only, and 1970s only. The respecified model, as such, was less satisfactory for explaining the influence of four-lane highways on 1980 s employment addition, however. Although the F statistics indicated that the coefficients of the respecified model differed significantly from zero for both durable and nondurable industries, the R-square statistics were comparatively smaller (.31 [durable] and .10 [nondurable]. These results suggest that the original model explained variation in 1980s employment addition slightly better than did the respecified model omitting the contemporaneous variables.

\section{v. CONCLUSIONS}

Several points of interest for state policymakers may be gleaned from the empirical results presented here. First, agglomeration forces, as approximated by regions with greater than average initial employment levels, provide a consistently positive influence on durable and nondurable manufacturing employment creation. Where a region is, however, with respect to its proximity to an urban core area, appears to have some bearing on the industry location decision. The coefficient signs are negative and significant for the threshold (nondurable) and rural (durable) variables supporting the notion that isolation from agglomeration economies may negatively influence job growth.

With respect to transportation provisions, durable manufacturing industries stand much to gain from having proximity to I-85, access to an interstate highway, and added two-lane road density. Four-lane highways have a positive contribution to durable manufacturing industry development, although timing of project investment appears to matter. For nondurable manufacturing industries, only access to interstate highways and four-lane highways constructed during the 1980s have significant positive influences on job creation. Industrial water and sewer capacity in a region appear to be a necessary infrastructure expenditure for attracting new firms in both the durable and nondurable industries in South Carolina, although the impact is comparatively small.

In sum, these results suggest that the location, timing, and type of highway project investment influences its impact on manufacturing job creation. The consistent role of agglomeration forces, as approximated with employment density, suggests that increased highway investment in regions with above average 
employment levels would stimulate continued industry and business development. It also suggests that comparatively less developed regions would benefit from economic development strategies that reach beyond industrial recruitment through highway investment incentives. If highway investment, for the purpose of generating jobs, is destined for these lesser developed regions, then type of highway investment (interstate access, four lane, or two lane, for example) may be critical to realizing positive results. Also important in such an investment allocation decision is where the region is with respect to developed urban core areas. These results raise the concern that those more isolated regions may not respond as positively to investment as would a region in or immediately around an urban core. These findings are consistent generally with previous empirical work, outlined by Rephann (1993), emphasizing the role that "triggering forces" play in the regional growth process.

More efforts should be made to explore the public capital hypothesis at the small region level within state boundaries. The tools are readily available for testing and correcting for spatial concerns unique to small region models that in the past have only been discussed, avoided, or dismissed. With a current focus on state and local policies designed to produce positive economic impacts, there is a critical need for more innovative small region analyses. This need will likely require broader thinking as well as further efforts to combine spatial analytical techniques with conventional econometrics.

\section{ENDNOTES}

1. The indirect profit function, $\pi^{*}$, is $\pi^{*}{ }_{2}=\pi^{*}{ }_{2}\left(D, S, w, p, G, t_{l}, t_{2}\right)$, whereby (D) represents size of existing market, (S) represents number of competitors and quantity, and $\left(t_{1}\right)$ represents tax costs of value of firm sales, e.g., local sales tax. Production costs that are reduced to yield profits include: factor prices $(w)$, taxes imposed on firms' factor inputs $\left(t_{2}\right)$, factor productivity $(p)$, the output to be produced, and the government services $(G)$ available at the site (Fox and Murray $1990,416)$.

2. The welfare function is constructed to represent the manager's siting decision for each possible location within a region as $W_{m}=W(\pi, A)$. The welfare level $(W)$ of the firm manager $(m)$ is a function of profits $(\pi)$ expected in each potential location and set of amenities (A).

3. Earlier tests showed that a $5 \mathrm{~km}$ distance buffer was a reasonable distance to test for association between employment change and highway investment. Tests for regions located $5.01 \mathrm{~km}$ to $10 \mathrm{~km}$ from highway projects showed little association between four-lane highways and employment change. 
4. Although regional "stage of development" may also reflect level of agglomeration economy, proxies for stage of development (regions clustered by income and labor force participation rates) in earlier tests were found to be collinear with employment density and subsequently were omitted from the equation.

5. The South Carolina State Development Board created the geocoded data as part of a statewide strategic planning initiative for economic development. The initiative included compiling and geocoding data for water and sewerage, highways, and ultimately utility lines, railroads, airports, and shipping ports.

\section{REFERENCES}

Anselin, Luc. Spatial Econometrics: Methods and Models. Boston: Kluwer Academic Publishers, 1989.

Aschauer, David A. "Highway Capacity and Economic Growth," Economic Perspectives (Federal Reserve Bank, Chicago) 14, no. 5 (September/October 1990): 14-24.

Arthur, W. Brian. "Competing Technologies, Increasing Returns, and Lock-In by Historical Events" The Economic Journal 99 (March 1989): 116-131.

Baerwald, Thomas J. "Land Use Change in Suburban Clusters and Corridors." In Transportation Research Record 861. Washington, D.C.: Transportation Research Board, National Research Council, 1982, 7-12.

Bartik, Timothy. Who Benefits from State and Local Economic Development Policies? Kalamazoo, Mich.: W.E. Upjohn Institute, 1991.

Bernirschka, Martin. "Farmland Value Changes, Grain Storage, and Livestock Production in a Geographically Dispersed Market." Unpublished Ph.D. dissertation, Purdue University, 1990.

Briggs, Ronald. "The Impact of the Interstate Highway System on Nonmetropolitan Growth." DOT Report RC-92040. Springfield, Virginia, NTIS, 1980.

Burress, David, and Norman Clifford. "Some Effects of Government on the Growth of Kansas Counties." Paper presented at the Southern Regional Science Association Annual Meetings, 1989.

Calzonetti, F. J., and Robert T. Walker. "Factors Affecting Industrial Location Decisions: A Survey Approach." In Industry Location and Public Policy, edited by Henry W. Herzog, Jr. and Alan M. Schlottmann. Knoxville, Tenn.: The University of Tennessee Press, 1991.

Cliff, A. D., and J. K. Ord. Spatial Processes: Models and Applications. London: Pion Limited, 1981. 
Eberts, Randall. "Public Infrastructure and Regional Economic Development." Economic Review (Federal Reserve Bank of Cleveland) 26, no. 1 (1990):1527.

. "Some Empirical Evidence on the Linkage between Public Infrastructure and Local Economic Development." In Industry Location and Public Policy, edited by Henry W. Herzog, Jr. and Alan M. Schlottmann. Knoxville, Tenn.: The University of Tennessee Press, 1991.

Fox, William F. and Murray, M. "Local Public Policies and Interregional Business Development." Southern Journal of Economics 22 (October 1990): 413427.

"The Effects of Local Government Public Policies on the Location of Business Activity." In Industry Location and Public Policy, edited by Henry W. Herzog, Jr. and Alan M. Schlottmann. Knoxville, Tenn.: The University of Tennessee Press, 1991.

Gerking, Shelby, and William Morgan. "Measuring Effects of Industrial Location and State Economic Development Policy: A Survey." In Industry Location and Public Policy, edited by Henry W. Herzog, Jr. and Alan M. Schlottmann. Knoxville: University of Tennessee Press, 1991.

Hausman, J.A. "Specification Tests in Econometrics." Econometrica 46 no. 6 (1978): 1251-1272.

Henry, Mark S. "Modelling Regional Economic Change with the Aid of Geographic Information Systems: Authentic Regional Science?" Presidential Address to the Southern Regional Science Association, Miami, Florida, April 12, 1991.

Humphrey, Craig R., and Ralph R. Sell. "The Impact of Controlled Access Highways on Population Growth in Pennsylvania Nonmetropolitan Communities, 1940-1970." Rural Sociology 40, no. 3 (1970): 332-343.

Isserman, Andrew M., Terence Rephann, and David J. Sorenson. "Highways and Rural Economic Development: Exploratory Results from Quasi-Experimental Approaches." Southern Regional Science Association, Proceedings, 1989.

Krugman, Paul. "Increasing Returns and Economic Geography." Journal of Political Economy 99, no. 3 (June 1991):483-499.

Kuehn, John A., and Jerry G. West. "Highways and Regional Development." Growth and Change 2, no. 3 (1971): 23-35.

Miller, James P. "Interstate Highways and Job Growth in Nonmetropolitan Areas: A Reassessment." Transportation Journal 9, no. 1 (1979): 78-86.

Munnel, Alicia. "How Does Public Infrastructure Affect Regional Economic Performance?" New England Economic Review (September/October 1990): 12 32. 
Nijkamp, Peter. "Infrastructure and Regional Development: A Multidimensional Policy Analysis" Empirical Economics 11 (1986):23-32.

Rephann, Terance J. "Highway Investment and Regional Economic Development: Decision Methods and Empirical Foundations," Urban Studies, Vol. 30, No. 2:437-450.

Richardson, H.W. Regional Economics. London: Weidenfield and Nicholson, 1969.

Storper, Michael. "Technologies and New Regional Growth Complexes: The Economics of Discontinuous Spatial Development." In Technological Change, Employment, and Spatial Dynamics, edited by Per Nijkamp. New York: Springer-Verlag, 1986.

Tatom, John A. "Public Capital and Private Sector Performance." Review: Federal Reserve Bank of St. Louis 73, no. 3 (1991):3-15.

Wilson, F.R., G.M. Graham, and Mohamed Aboul-ela. "Highway Investment as a Regional Development Policy Tool." Transportation Research Record 1046, TRB, National Research Council, Washington, D.C.:10-17, 1985. 